\title{
HYDRODYNAMIC MODELING OF A COMPLEX KARST-ALLUVIAL AQUIFER: CASE STUDY OF PRIJEDOR GROUNDWATER SOURCE, REPUBLIC OF SRPSKA, BOSNIA AND HERZEGOVINA
}

\author{
HIDRODINAMIČNO MODELIRANJE ZAPLETENEGA KRAŠKO- \\ ALUVIALNEGA VODONOSNIKA: ŠTUDIJA NA PRIMERU VODNEGA \\ VIRA PRIJEDOR, REPUBLIKA SRBSKA V BOSNI IN HERCEGOVINI
}

\author{
Dušan POLOMČIĆ ${ }^{1}$, Veselin DRAGIŠIĆ ${ }^{1} \&$ Vladimir ŽIVANOVIĆ ${ }^{1}$
}

\begin{abstract}
UDC 556.3:551.44(497.6)

Dušan Polomčić, Veselin Dragišić \& Vladimir Živanović: Hydrodynamic modeling of a complex karst-alluvial aquifer: case study of Prijedor Groundwater Source, Republic of Srpska, Bosnia and Herzegovina

Middle Triassic fractured and karstified limestone and dolomite form a karst aquifer in the Sana River Valley near the town of Prijedor. As a result of intensive tectonic movements, carbonate rocks are mostly below the Sana River level, covered by younger Pliocene and alluvial deposits. The main source of groundwater recharge is infiltration from the Sana River through its alluvium over most of the aquifer. The main objective of the research reported in this paper was to evaluate the hydraulic relationships of the alluvial, Pliocene and karst aquifers in order to better understand the water supply potential of the karst aquifer. Although the use of hydrodynamic modeling is not very common with karst aquifers, the developed model provided significant and useful information on the groundwater budget and recharge type. The influence of fault zones and spatial anisotropy of the karst aquifer were simulated on the hydrodynamic model by varying permeability on the $\mathrm{x}$ and y-axes of the Cartesian coordinate system with respect to the fault, the main pathway of groundwater circulation. Representative hydraulic conductivities were $\mathrm{K}_{\mathrm{x}}=2.3 \cdot 10^{-3} \mathrm{~m} / \mathrm{s}$ and $\mathrm{K}_{\mathrm{y}}=5.0 \cdot 10^{-3} \mathrm{~m} / \mathrm{s}$ in the faults of NW to SE direction, and $\mathrm{K}_{\mathrm{x}}=2.5 \cdot 10^{-3} \mathrm{~m} / \mathrm{s}$ and $\mathrm{K}_{\mathrm{y}} 1.2 \cdot 10^{-3} \mathrm{~m} / \mathrm{s}$ in the faults of SW to NE trend. Model research showed that the karst aquifer can be used in the long term at maximal tested capacities and that current groundwater exploitation is not compromised in dry periods when the water budget depends entirely on recharge from the Sana River.

Key words: Triassic carbonate rocks, karst aquifer, spatial anisotropy, hydrodynamic model, karst-alluvial aquifer interrelation, groundwater budget.
\end{abstract}

Povzetek UDK 556.3:551.44(497.6)

Dušan Polomčić, Veselin Dragišić \& Vladimir Živanović: Hidrodinamično modeliranje zapletenega kraško-aluvialnega vodonosnika: študija na primeru vodnega vira Prijedor, Republika Srbska $v$ Bosni in Hercegovini

Srednje triasni zakraseli apnenec in dolomit tvorijo kraški vodonosnik v dolini reke Sane blizu mesta Prijedor. Kot posledica intenzivnih tektonskih premikov, se karbonatne kamnine nahajajo večinoma pod nivojem reke in so prekriti z mlajšimi plastmi pliocenske starosti in aluvialnimi naplavinami. Glavni vir napajanja podzemne vode je v precejšnjem delu vodonosnika infiltracija skozi naplavino iz reke Sane. Glavni cilj pričujoče raziskave je bila ocena hidravličnih odnosov med aluvialnim, pliocenskim in kraškim vodonosnikom, da bi bolje razumeli potencial kraškega vodonosnika za vodooskrbo. Čeprav hidrodinamično modeliranje kraških vodonosnikov ni zelo pogosto, je razviti model prinesel pomembne in koristne informacije o vodni bilanci podtalnice in o vrsti napajanja. Vpliv prelomov in prostorske anizotropije kraškega vodonosnika smo simulirali na hidrodinamičnem modelu s spreminjanjem prepustnosti na $\mathrm{x}$ in $\mathrm{y}$ oseh Kartezijanskega koordinatnega sistema $\mathrm{z}$ ozirom na prelom, glavno pot kroženja podzemne vode. Reprezentativne vrednosti hidravlične prevodnosti so $\mathrm{K}_{\mathrm{x}}=2.3 \cdot 10^{-3} \mathrm{~m} / \mathrm{s}$ in $\mathrm{K}_{\mathrm{y}}=5.0 \cdot 10^{-3} \mathrm{~m} / \mathrm{s}$ za prelome smeri SZ $-\mathrm{JV}$, ter $\mathrm{K}_{\mathrm{x}}=2.5 \cdot 10^{-3} \mathrm{~m} / \mathrm{s}$ in $\mathrm{K}_{\mathrm{y}} 1.2 \cdot 10^{-3} \mathrm{~m} / \mathrm{s}$ za prelome smeri JZ - SV. Raziskava je pokazala, da se kraški vodonosnik lahko izrablja na dolgi rok pri maksimalnih testiranih zmogljivostih in da trenutno izkoriščanje podzemne vode ni ogrožena niti v sušnih obdobjih, ko je napajanje vodonosnika zgolj iz reke Sane.

Ključne besede: triasne karbonatne kamnine, kraški vodonosnik, prostorsko anizotropija, hidrodinamični model, kraškoaluvialni vodonosnik, vodna bilanca podtalnice.

\footnotetext{
${ }^{1}$ University of Belgrade, Faculty of Mining and Geology, Department of Hydrogeology, Djusina 7, 11000 Belgrade, Serbia, e-mail: dupol2@gmail.com; v.dragisic@rgf.bg.ac.rs; v.zivanovic@rgf.bg.ac.rs
}

Received/Prejeto: 20.03.2012 


\section{INTRODUCTION}

Numerical groundwater modeling has become a basic technique for proper groundwater management. Numerical models can be used to determine the hydraulic parameters and groundwater budget, and to predict aquifer behavior in new hydrologic and hydraulic circumstances related to groundwater management or climate change. However, classical numerical models have serious limitations in modeling karst groundwater flow, since Darcy's law cannot be applied (Field 1997).

In addition to the primary porosity, karst terrains are characterized by secondary porosity that occurs in the form of a system of cracks and faults, and tertiary (dissolution) porosity that is usually represented by systems of connected channels of different dimensions (Ford \& Williams 2007). Because of the high heterogeneity and anisotropy of the hydraulic parameters of a karst environment, the determination of their distribution in the karst system is always coupled with approximation, first related to the conceptual hydrogeological model, in most porous unconsolidated aquifers (Kovacs \& Sauter 2007). However, over the past two decades numerical models of groundwater flow have been developed to study the impact of heterogeneity on hydraulic parameters, and therefore on the karst aquifer as well (Király 2003).

There are three ways to characterize karst environments. The simplest and most commonly used method is to assume that a karst aquifer is equivalent to a porous medium in which karst channels and large faults are treated as areas featuring high hydraulic conductivities (Teutsch 1993; Scanlon et al. 2003). The second approach is to use dual porosity or dual permeability models (Mohrlok et al. 1997; Cornaton \& Perrochet 2002). The third approach is a combination of linear flow and nonlinear flows, using the concept of equivalent hydraulic conductivity from Darcy's law (Cheng \& Chen
2004). In their previous work, the authors of this paper successfully applied the first approach to hydrodynamic modeling of karst on the Bogovina karst system in Serbia (Stevanović \& Dragišić 1997) and on the karst massif of Mt. Stara Planina, also in Serbia (Polomčić 2012).

The application of hydrodynamic models based on simulating water movement through a channel network is limited for regional karst aquifers mostly because of a lack of database, the saturation level of the aquifer, or difficulty in simulating spatial anisotropy. In such cases a mixed numerical method of finite difference, which assumes that the karst aquifer can be schematized by a continuum model with special attention to preferential pathways of groundwater circulation, can be applied.

An example of this is a regional karst aquifer located in the extended area of the town of Prijedor in the Republic of Srpska (Bosnia and Herzegovina). This karst aquifer is highly specific because it is very shallow beneath the surface and extensively covered with alluvial sediments of the Sana River with which it is in direct hydraulic connection.

The main objective of this research was to determine the possibility of applying a mixed hydrodynamic model of the continuum model in the presence of preferential pathways of groundwater flow, in order to evaluate recharge and drainage conditions of this regional aquifer. The developed model was used to explain many unclear issues like the contributions of the main components of the groundwater budget, the groundwater flow directions, the potential for increasing exploitation etc. The model was also used to justify an additional $152 \mathrm{l} / \mathrm{s}$ of groundwater pumped from two new wells (B-7 and B-8), and to show that their operation together with the older wells is possible and sustainable.

\section{MATERIALS AND METHODS}

The hydrodynamic model of the Prijedor groundwater source was developed using numerous data from geophysical exploration, borehole drilling, well testing, groundwater monitoring, and the like. The first significant investigations for water supply purposes of the city of Prijedor were conducted during the 1970s and 1990s. Extensive geophysical surveys were undertaken to detect the directions of fault structures and to define the extent of lithologic members, as well as to identify prospective zones for locating new water supply wells.
Based on the results of these investigations, in 2002 and 2003 a number of piezometers were installed with the aim to define the exact contact of alluvial and karst aquifers and to determine the micro-locations of the wells that will expand the current groundwater source. Some of these piezometers (IBM-1 to IBM-8) were screened across the karst aquifer while others (DP-1 to DP-5) were screened across the alluvial aquifer. One deep structural borehole (IBMS-1) was drilled to determine the degree of karstification up to $150 \mathrm{~m}$. In 2003, wells B-7 and B-8 
were completed and pumping tests conducted. The hydrogeological parameters of different lithological units were determined by pumping test analysis, where possible, and analysis of grain-size curves.

Groundwater level fluctuations were monitored at the installed wells and piezometers from 2002 to 2004.
The monitoring program also included changes in the Sana River water levels and climate data. The results of all the above-mentioned investigations were used as a basis for the formation of a three-dimensional groundwater flow model.

\section{STUDY AREA}

Geology. The study area is built of rocks formed during the Paleozoic, Mesozoic, Neogene and Quaternary ages (Fig. 1).

The Paleozoic consists of undifferentiated Lower and Middle Carboniferous $\left(\mathrm{C}_{1+2}\right)$ sandstone, clay slate, siltstone and rare conglomerate. Inclusions of limestone, dolomite and siderite are also common (Jurić 1970, 1977; Grubić et al. 2000; Cvijić 2004).

The rocks formed during the Mesozoic are represented by Lower and Middle Triassic sediments that build the basement of Neogene deposits (Jurić 1977). The Lower Triassic $\left(\mathrm{T}_{1}\right)$ consists of sedimentary clastic rocks: sandstone, thin layered to laminated limestone, marlstone and rare dolomite, with sandstone and schist prevailing. The Middle Triassic $\left(\mathrm{T}_{2}{ }^{1}\right)$ mainly features carbonate rocks: dolomite, dolomitic limestone and limestone. Triassic carbonate rocks are covered by Pliocene sediments in most of the research area. West of Prijedor, Triassic sediments are in direct contact with alluvial sediments.

Neogene sediments were deposited during the Pliocene age and are characterized by high diversity. They consist of silty sand, sand, gravel and sandy and coal clays. These sediments are mostly covered by younger Quaternary deposits.

The Sana River alluvium (al) is the dominant Quaternary deposit widespread on the surface and less than ten meters thick (Figs. 1 and 3). It is composed of coarse gravel and sand. Terrace gravel and sand ( $\mathrm{t}$ ) also are Quaternary.

As for the tectonics, the study area is characterized by two structural-facial units: zone of Paleozoic schist and Mesozoic limestone and zone of the Prijedor Neogene basin (Jurić 1977). Numerous fault structures are present with dominant northwest-southeast and northeast-southwest directions (Fig. 2). The northeastern part of the area has been downthrown along the fault zone in the northwest-southeast direction, which generally coincides with the flow direction of the Sana River (Fig. 3). Another fault in the southern part of the study area brought Triassic limestone and dolomite to the same hypsometric level with Paleozoic clastic and metamorphic rocks. Mesozoic carbonates are absent south of this tectonic zone, which is about $400 \mathrm{~m}$ from wells B-1 and $\mathrm{B}-2$.

Hydrogeology. The presence of diverse petrographic types and different rock porosities resulted in the following types of aquifers: alluvial aquifer, karst aquifer and intergranular aquifer in Pliocene sediments (Fig. 1). The terrains made up of low permeable rocks were identified as a separate hydrogeological unit (Fig. 3).

The alluvial aquifer of recent coarse gravels and sands, 3.5 to 10 meters thick, has a hydraulic conductivity $(\mathrm{K})$ of $1 \cdot 10^{-3} \mathrm{~m} / \mathrm{s}$ and its transmissivity $(\mathrm{T})$ is from $6 \cdot 10^{-4}$ to $1.6 \cdot 10^{-3} \mathrm{~m}^{2} / \mathrm{s}$ (Jovanović et al. 1998). The main source of groundwater recharge is the Sana River.

This aquifer was the main source of water supply to Prijedor until the late 1970s. The minimum flow of the Sana River in the dry season, insufficient to replenish groundwater, was a serious water supply issue. Low stages of the Sana also caused a reverse process, groundwater flow to the river (Josipović 1971; Polomčić et al. 2005a).

Pliocene hydrogeological complex. The Pliocene rock complex forms two layers. The lower consists of permeable fine-grained sand and sandy gravel in the Tukovi area and of gravel on the right bank of the Sana in the north. These rocks form an intergranular subartesian aquifer (Polomčić et al. 2005a). The upper layer is represented by impermeable clay sediments.

The karst aquifer is formed in Middle Triassic dolomite and limestone that are sufficiently fractured and karstified to store large amounts of groundwater. The aquifer widens to the north and north-west. It has a limited distribution to the south and south-east because of the presence of low permeable rocks (Paleozoic schist and Lower Triassic clastics) (Ostojić 1974). The karst aquifer is recharged by surface water infiltration from the Sana River through the partially overlying alluvial aquifer (Fig. 4) and by infiltration of precipitation through about $1 \mathrm{~km}^{2}$ of its exposure in the north-west of the study area (Fig. 1). The wells drilled in Mataruško 


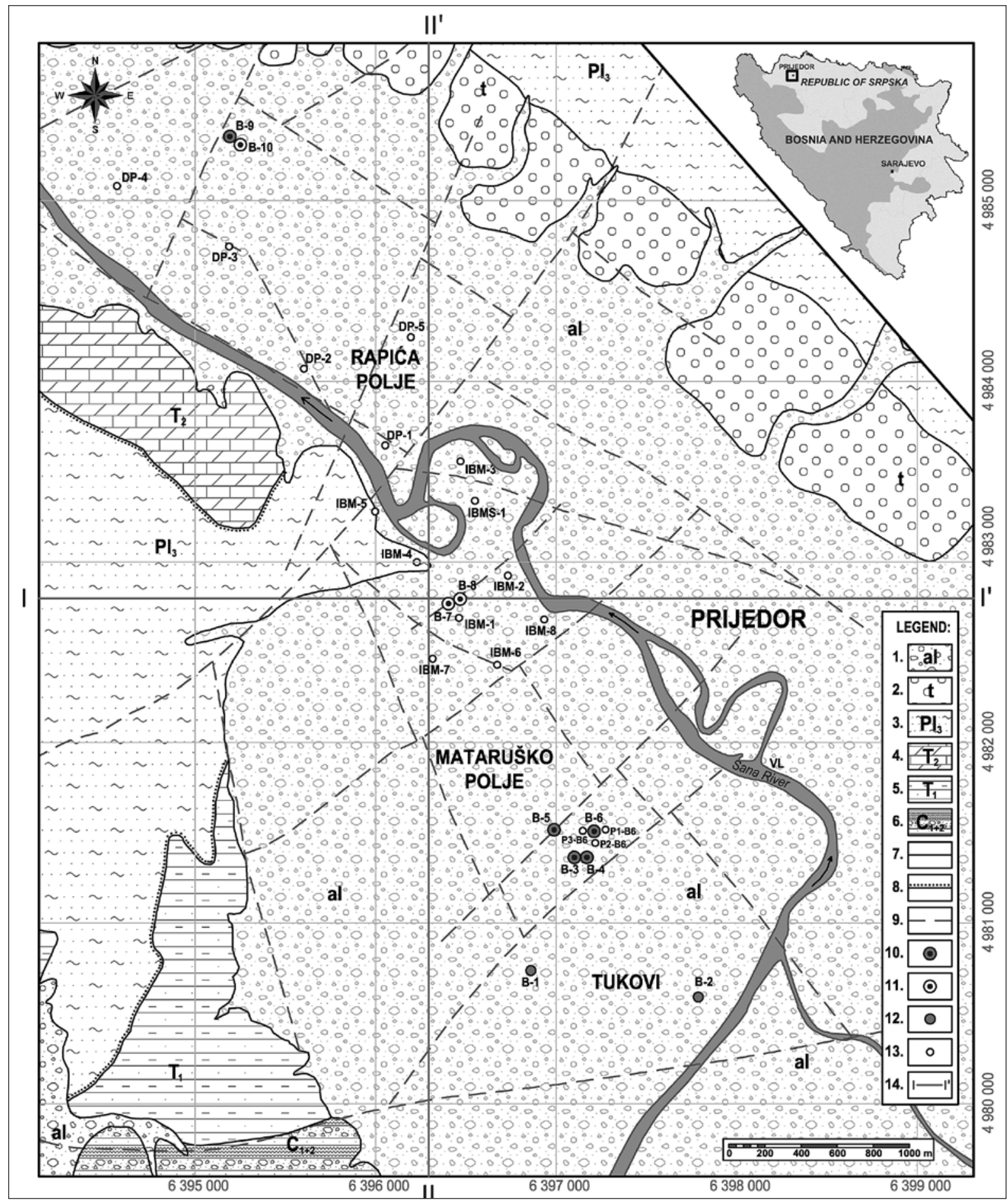

Fig. 1: Geological map of the study area (Polomčić et al. 2005a, modified).

1. Alluvial gravel and sand (intergranular aquifer); 2. Terrace gravel and clay sand (intergranular aquifer); 3. Sandy clay and silty sand (Pliocene hydrogeological complex); 4. Limestone and dolomite (karst aquifer); 5. Sandstone, schist, limestone and marlstone (low permeable rocks); 6. Sandstone, clay slate, siltstone and conglomerate (low permeable rocks); 7. Normal geological boundary; 8. Transgressive geological boundary; 9. Normal fault, approximately located; 10. Production well (karst aquifer); 11. Observation well (karst aquifer); 12. Production well (alluvial aquifer); 13. Piezometer; 14. Cross-section line. 


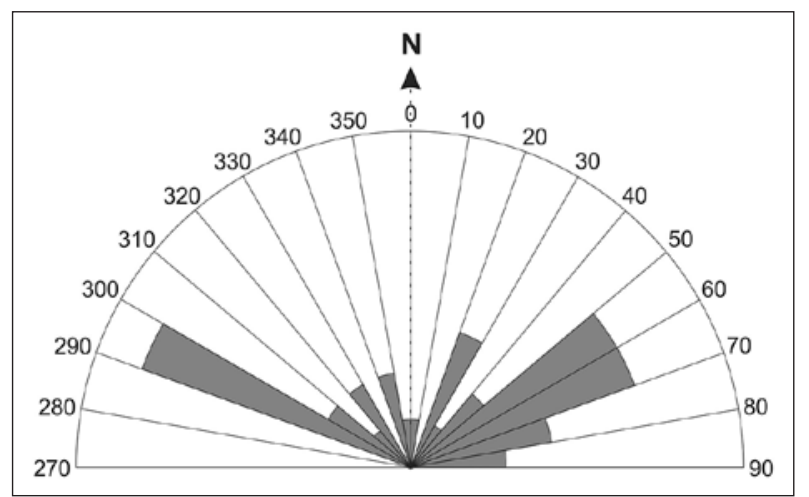

Polje and Prijedorčanka groundwater source areas indicated the existence of highly permeable carbonate rocks characterized by a pumping rate of up to $80 \mathrm{l} / \mathrm{s}$ per well (Josipović 1971; Jovanović et al. 1998; Polomčić et al. 2005a).

Low permeable rocks. Carboniferous metamorphic and Lower Triassic clastic rocks have been assigned to the group of low-permeable rocks. In relation to the Triassic karst aquifer, these rocks function as the lower boundary of the aquifer, and as groundwater barriers.

Fig. 2: Rose diagram showing fault orientation in the study area.

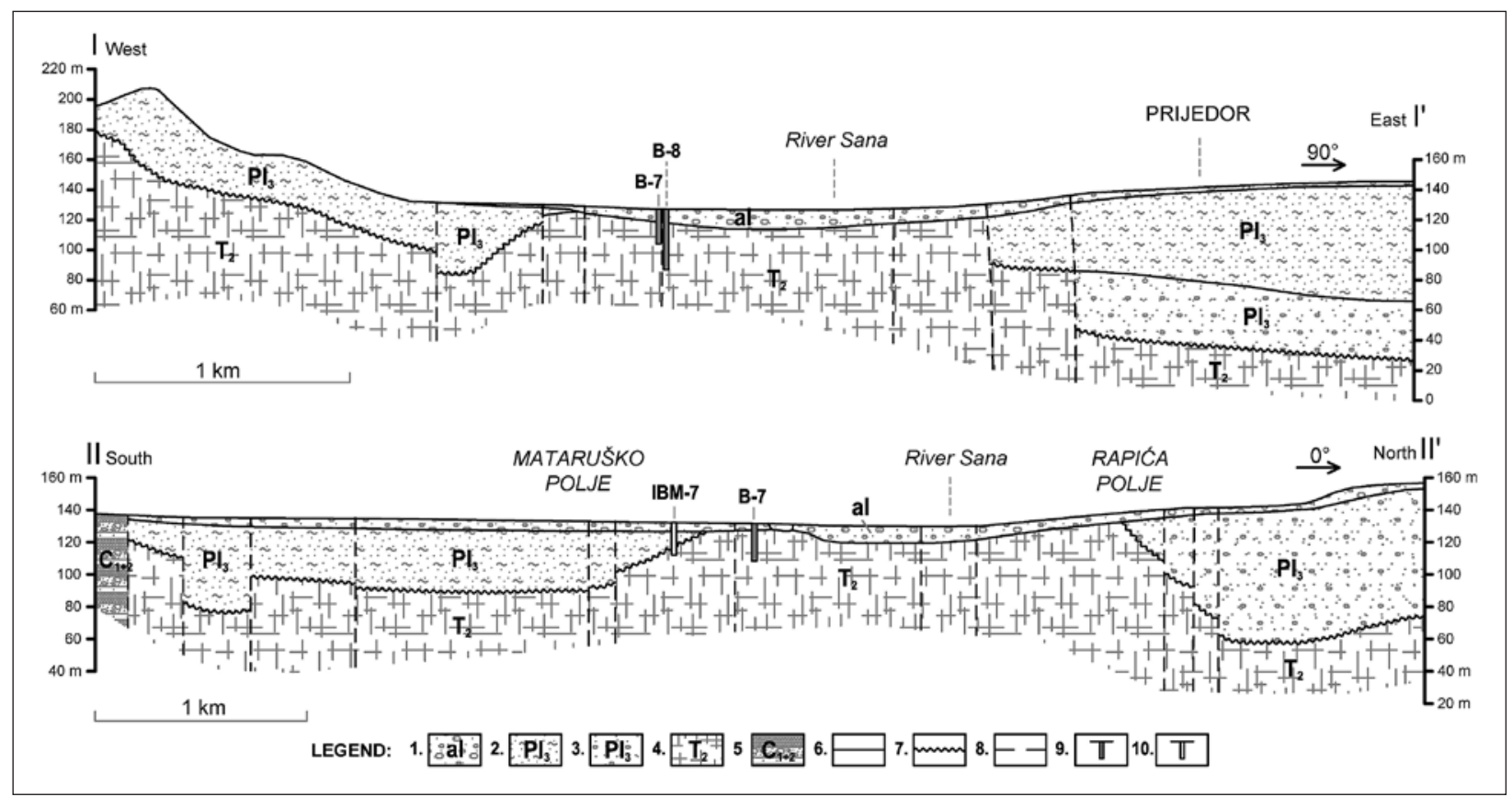

Fig. 3: Geological cross-sections.

1. Alluvial gravel and sand (alluvial intergranular aquifer); 2. Sandy clay (aquitard); 3. Sand-gravelly sediments (intergranular aquifer); 4. Limestone and dolomite (karst aquifer); 5. Sandstone, clay schists, siltstone and conglomerate (low permeable rocks); 6. Normal geological boundary; 7. Transgressive geological boundary; 8. Fault, approximately located; 9. Well; 10. Piezometer. 


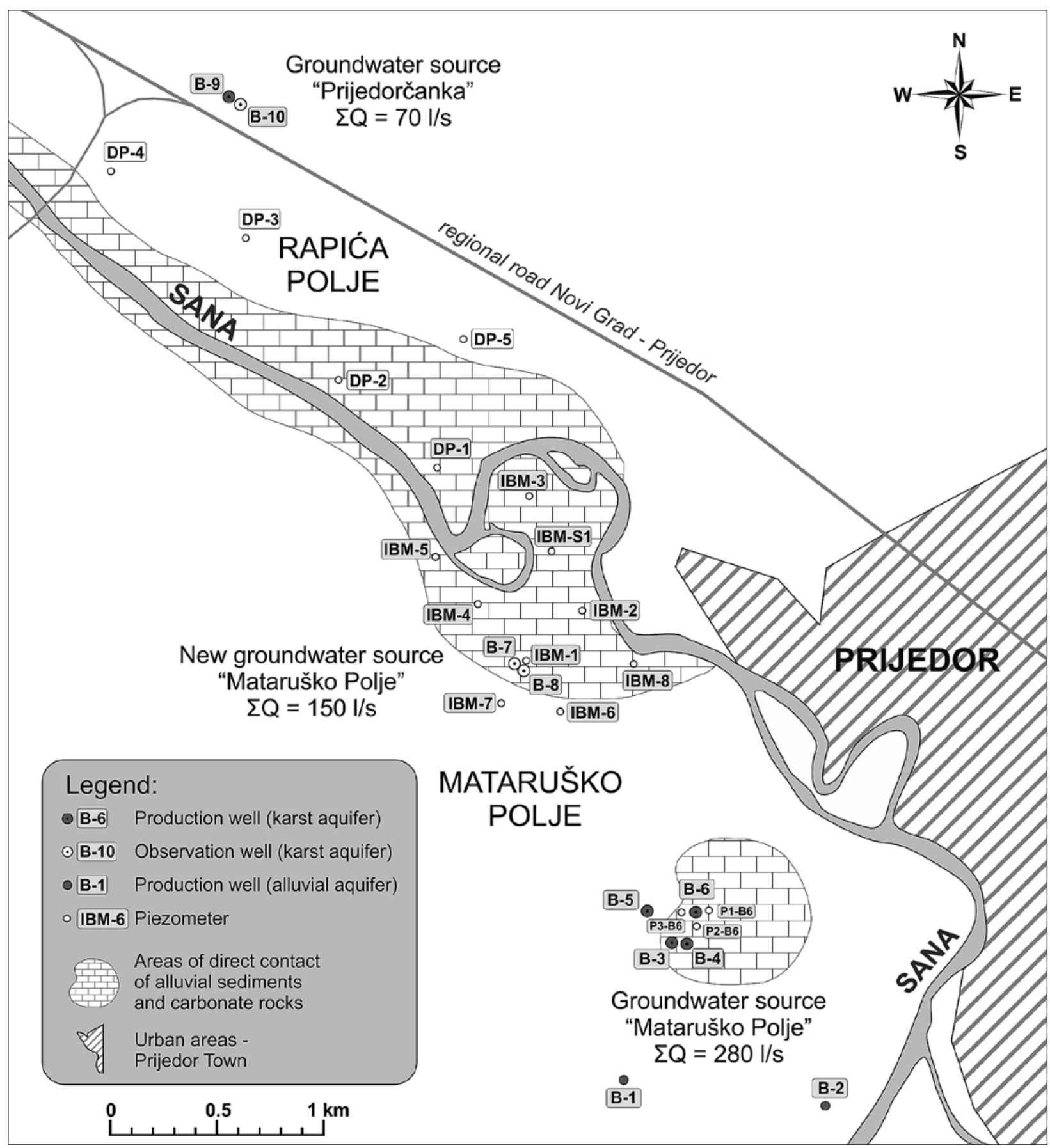

Fig. 4: Contact zone of alluvial gravel and karstified Triassic carbonate rocks in Mataruško Polje and Prijedorčanka source areas (contact zone defined according to geophysical and piezometer/well drilling data).

\section{GROUNDWATER EXPLOITATION}

The source area at Mataruško Polje has six production wells on the left bank of the river. Two shallow wells (B-1 and $\mathrm{B}-2$ ) are active only during periods of high stream- flows, pumping about $10 \mathrm{l} / \mathrm{s}$ from the Sana alluvial aquifer. The other four wells (B-3, B-4, B-5 and B-6) are deeper $(19-50 \mathrm{~m})$, extracting $210 \mathrm{l} / \mathrm{s}$ from the Triassic 
karst aquifer (Figs. 1 and 4). Two new wells, B-7 $(23 \mathrm{~m})$ and B-8 $(40 \mathrm{~m})$, also extract water from the karst aquifer. During pump testing of the two new wells at a total rate of $152 \mathrm{l} / \mathrm{s}$, the resulting drawdown was only $1.51 \mathrm{~m}$ (Polomčić et al. 2005a). The addition of the new wells to the existing system will significantly improve the water supply to Prijedor.
Wells B-9 and B-10 (Figs. 1 and 4) were drilled in the Prijedorčanka area on the right bank of the Sana. Well B-9 (74 m deep) is currently operational, extracting groundwater at a rate of $70 \mathrm{l} / \mathrm{s}$, while well B-10 is used as an observation well.

\section{GROUNDWATER REGIME}

Groundwater observation records on the wells and the Sana River were a reliable data source for a hydrodynamic analysis of the groundwater regime of the Sana Valley karst aquifer. The groundwater level was mostly lower than the water level of the Sana River throughout the observation period, from 15 Nov. 2002 to 16 Sep. 2004. Each change in the river water level almost instantaneously affected groundwater levels at all piezometers (Fig. 5). It should be noted that the Sana dropped below the zero-level from 18 July to $12 \mathrm{Sep}$. and from 21 to $25 \mathrm{Sep}$. 2003. A similar hydrologic situation has not been registered over the hundred years of record keeping.
Fig. 6 shows the correlation between measured depths to the water table and the Sana water levels during individual and group (wells B-7 and B-8) tests and their effect observed at the surrounding piezometers. The same figure shows two zones of notable (B-7 and B-8) pumping effect on the groundwater levels observed at piezometers $\mathrm{P} 1-\mathrm{B} 6, \mathrm{P} 2-\mathrm{B} 6$ and $\mathrm{P} 3-\mathrm{B} 6$. This indicated a unified karst aquifer, locally eroded and filled with less permeable sediments, not zones of heavily fractured carbonate rocks as previously believed (Josipović 1971).

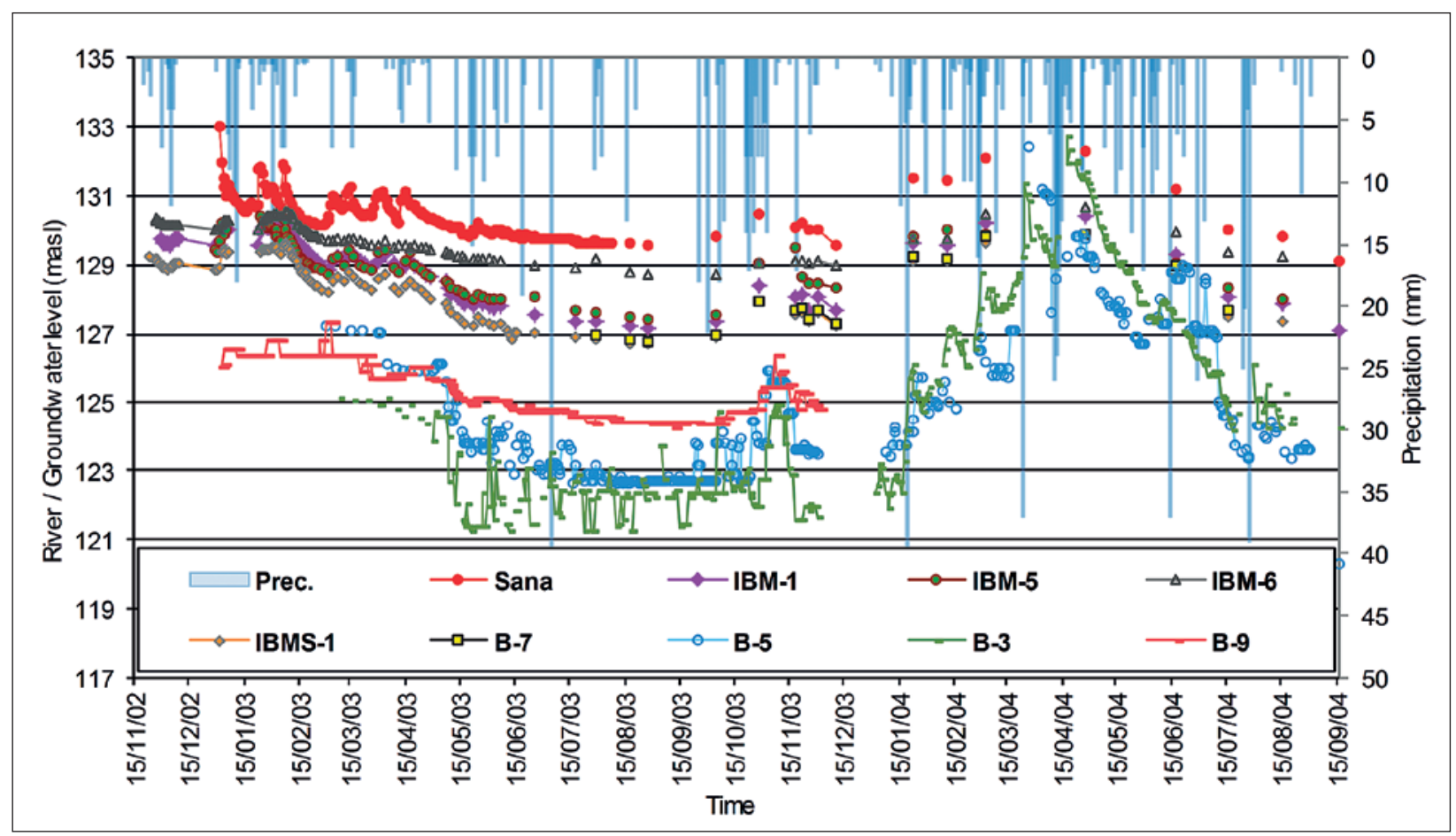

Fig. 5: Comparison of Sana River stage and groundwater level variations from 15 Nov. 2002 to 16 Sep. 2004. 


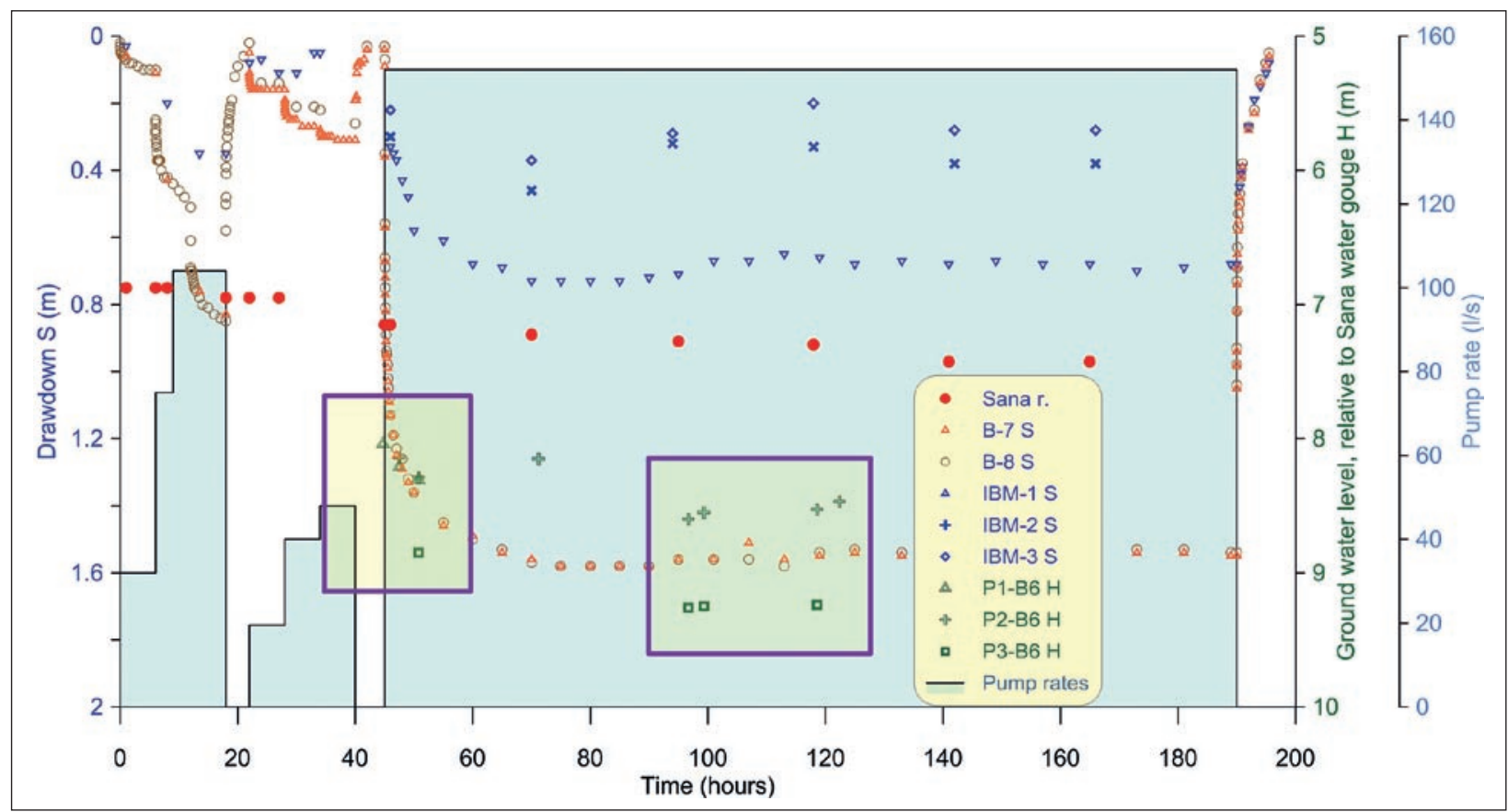

Fig. 6: Cones of depression formed around wells B-7 and B-8 and surrounding piezometers and respective water levels of the Sana during simultaneous tests of wells B-7 and B-8.

\section{HYDRODYNAMIC MODEL OF THE KARST AQUIFER}

The modeling concept for the Triassic karst aquifer was based on simulating three-dimensional groundwater flow. A layered model with the possibility of automatic variation of the flow field in relation to flow conditions was developed.

The code selected to develop the numerical model was MODFLOW-2000, a modular three-dimensional finite difference groundwater flow model developed by US Geological Survey (Harbaugh, et al.). The program used in this research was Groundwater Vistas 5.33b (Environmental Simulations International, Ltd.).

Karst aquifer flow field geometry and discretization. The hydrodynamic model of the karst aquifer in the Sana Valley was conceived and developed as a ten-layer model in the vertical section. A number of real layers, identified from abundant geological, geophysical and hydrogeological data, were put in several model layers to represent the interfaces of the lithological units as realistically as possible (Polomčić 2002). Table 1 describes the correspondent model and field layers, seen from the surface down.

The geometry of the groundwater production zones was simulated in plan view and vertical section using available data from the lithological logs of the wells and piezometers in the source areas, as well as the results of numerous geophysical surveys (Polomčić 2004; Polomčić et al. 2005b). The 191,820 cells of the model were arranged in 132 rows and 138 columns of ten model layers. The discretization of the flow field and schematized geometry of the lithological units in the study area are illustrated with schematized geological sections (Fig. 7).

Boundary conditions. The boundary conditions applied in the hydrodynamic model of the Triassic karst aquifer were the river boundary, a defined flow boundary, a general head boundary and effective infiltration.

River boundary. The only permanent surface body of water is the Sana River, whose influence on the karst aquifer was simulated by the river boundary in the first model layer (Fig. 9).

Flow boundary. The effect of the production wells in the source area was simulated applying the boundary condition for a pre-defined capacity, based on records of the well production rates and of the water table from 1 Jan. 2003 to 16 Sep. 2004 (Fig. 8).

In addition to the production wells in the two source areas, wells B-7 and B-8 located northwest of the Mataruško Polje groundwater source (Fig. 4) were simultaneously tested to quantify the effect on the wells 
Tab. 1: Field and model layers.

\begin{tabular}{|l|l|}
\hline Model layer & Lithological unit \\
\hline $\begin{array}{l}1^{\text {st }} \text { combined permeable- } \\
\text { impermeable layer }\end{array}$ & $\begin{array}{l}\text { Alluvial sediments on the left and right banks of the Sana over Triassic permeable de- } \\
\text { posits to the NE and over impermeable Neogene, Triassic and Carboniferous sediments } \\
\text { to the east, west and south. }\end{array}$ \\
\hline $\begin{array}{l}2^{\text {nd }} \text { to } 5^{\text {th }} \text { combined imper- } \\
\text { meable-permeable layers }\end{array}$ & $\begin{array}{l}\text { Triassic carbonate rocks in the NE, far NE and an isolated area at Tukovi surrounded by } \\
\text { Pliocene sandy gravel in the north and changing into low permeable Triassic schist and } \\
\text { marly limestone in the center and south, and Pliocene sandy clay. }\end{array}$ \\
\hline $\begin{array}{l}6^{\text {th }} \text { to } 9^{\text {th }} \text { combined perme- } \\
\text { able-impermeable layers }\end{array}$ & $\begin{array}{l}\text { Dominantly permeable layers of karstified Triassic limestone and dolomite in contact } \\
\text { with Pliocene sand in the central and eastern parts of the study area, and low permeable } \\
\text { Triassic and Carboniferous rocks in the SW. }\end{array}$ \\
\hline $10^{\text {th }}$ permeable layer & $\begin{array}{l}\text { Mainly permeable low karstified and tectonically deformed Triassic limestone and dol- } \\
\text { omite changing into low permeable Carboniferous rocks in the south. }\end{array}$ \\
\hline
\end{tabular}

in this source area, while they exerted no influence on the Prijedorčanka area (Polomčić et al. 2005b). Groundwater extraction from the wells in the two source areas and from wells B-7 and B-8 was simulated by the defined flow boundary.

General head boundary. The studied karst aquifer is also recharged beyond the limits of the research area covered by the model. The sources of groundwater recharge in the north and west of the research area were simulated by the general head boundary in the fourth model layer formed of karstified Triassic rocks (Fig. 9).

Effective infiltration. The 'vertical budget' or the resultant (effective) infiltration (difference between per-
Tab. 2: Target statistics.

\begin{tabular}{|l|c|}
\hline Residual Mean (m) & 0.03 \\
\hline Residual Standard Dev. (-) & 0.06 \\
\hline Absolute Residual Mean (-) & 0.06 \\
\hline Residual Sum of Squares (-) & $5.24 \cdot 10^{-2}$ \\
\hline RMS Error (m) & 0.07 \\
\hline Minimum Residual (m) & -0.09 \\
\hline Maximum Residual (m) & 0.10 \\
\hline Range of Observation (m) & 9.32 \\
\hline Scaled Std. Dev. (-) & 0.007 \\
\hline Scaled Abs. Mean (-) & 0.006 \\
\hline Scaled RMS (-) & 0.007 \\
\hline
\end{tabular}

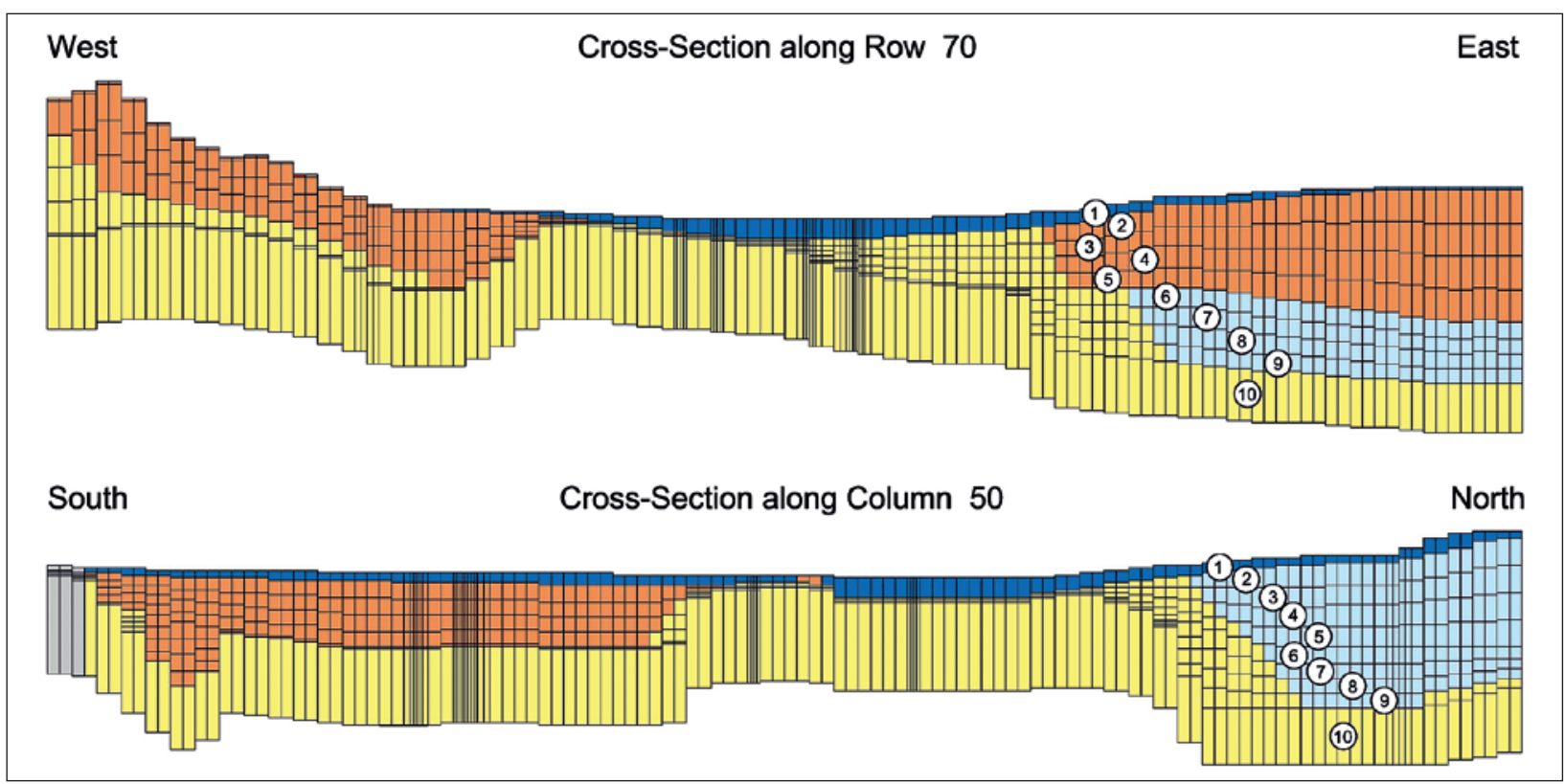

Fig. 7: Schematized geological sections through the Mataruško Polje source area (Legend: dark blue - alluvium; light blue - Pliocene sand and gravel; yellow - limestone and dolomite; brown - Pliocene clay, grey - Carboniferous metamorphic rocks; 1-10 - model layers (Tab. 1). 


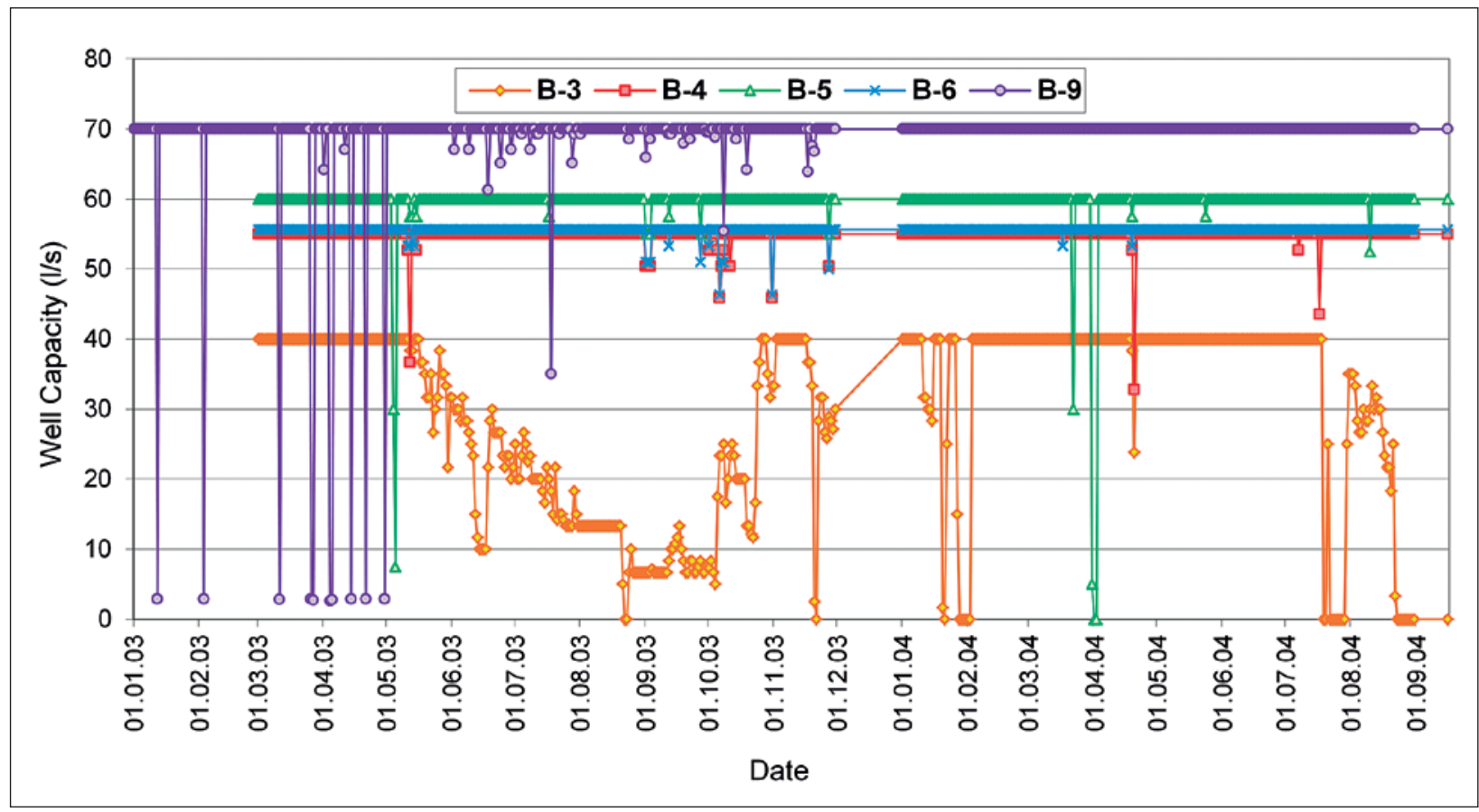

Fig. 8: Hydrographs of production wells in the Mataruško Polje and Prijedorčanka source areas for the period from 1 Jan. 2003 to 16 Sep. 2004.

colating rainfall and evapotranspiration) was assigned as $10 \%$ of the amount of precipitation, analogous to the surrounding areas (Bajić \& Polomčić 2008; Polomčić 2009). This boundary condition was specified only for the first model layer.

Model calibration. The model of the karst aquifer was calibrated for unsteady flow conditions, in one-day steps during the analyzed period (from 15 Nov. 2002 to 16 Sep. 2004), subdivided at the lower iteration level into 10 unequal (factor 1.2) intervals. The model computed and simulated real groundwater flow, confined or unconfined, individually in each discretization cell, varying the flow conditions over time in order to match real-life conditions.

Based on the positions of the groundwater contours and the residuals of the karst groundwater levels at the end of the tests at wells B-7 and B-8 (17 June 2003), it was safe to conclude that a satisfactory match of observed and computed groundwater levels was achieved (Fig. 9). Model calibration statistics are shown in Table 2.

The representative hydraulic parameters (Polomčić et al. 2005b; Polomčić 2009), determined through the model calibration process, are shown in Table 3.

Tab. 3: Representative hydraulic parameters of lithological units (Kx,y - horizontal hydraulic conductivity, Kz - vertical hydraulic conductivity, Ss - specific storage, Sy - specific yield).

\begin{tabular}{|l|c|c|c|c|}
\hline Lithostratigraphic units & $\mathbf{K x}, \mathbf{y}(\mathbf{m} / \mathbf{s})$ & $\mathbf{K z}(\mathbf{m} / \mathbf{s})$ & $\mathbf{S s} \mathbf{( 1 / m )}$ & Sy $(-)$ \\
\hline Alluvial gravel and sandy gravel & $5.00 \cdot 10^{-4}$ & $2.50 \cdot 10^{-4}$ & $2.25 \cdot 10^{-5}$ & 0.22 \\
\hline Terrace sand and gravel & $1.00 \cdot 10^{-4}$ & $1.00 \cdot 10^{-5}$ & $2.50 \cdot 10^{-5}$ & 0.23 \\
\hline Pliocene clay and sandy clay & $2.00 \cdot 10^{-6}$ & $1.00 \cdot 10^{-6}$ & $5.00 \cdot 10^{-5}$ & 0.06 \\
\hline Pliocene sandy gravel & $1.00 \cdot 10^{-4}$ & $1.00 \cdot 10^{-5}$ & $3.00 \cdot 10^{-5}$ & 0.20 \\
\hline \multirow{2}{*}{ Triassic limestone and dolomitic limestone (in fault zones) } & $2.00 \cdot 10^{-3-}$ & $2.0 \cdot 10^{-3-}$ & \multirow{2}{*}{$6.5 \cdot 10^{-4}$} & 0.17 \\
\hline Triassic limestone and dolomitic limestone (karstified) & $2.80 \cdot 10^{-4}$ & $2.80 \cdot 10^{-4}$ & & \\
\hline Triassic sandstone and schist & $1.44 \cdot 10^{-3}$ & $1.44 \cdot 10^{-3}$ & $3.25 \cdot 10^{-4}$ & 0.17 \\
\hline Carbonate sandstone, siltstone and schist & $5.00 \cdot 10^{-9}$ & $1.00 \cdot 10^{-9}$ & $6.10 \cdot 10^{-5}$ & 0.03 \\
\hline
\end{tabular}




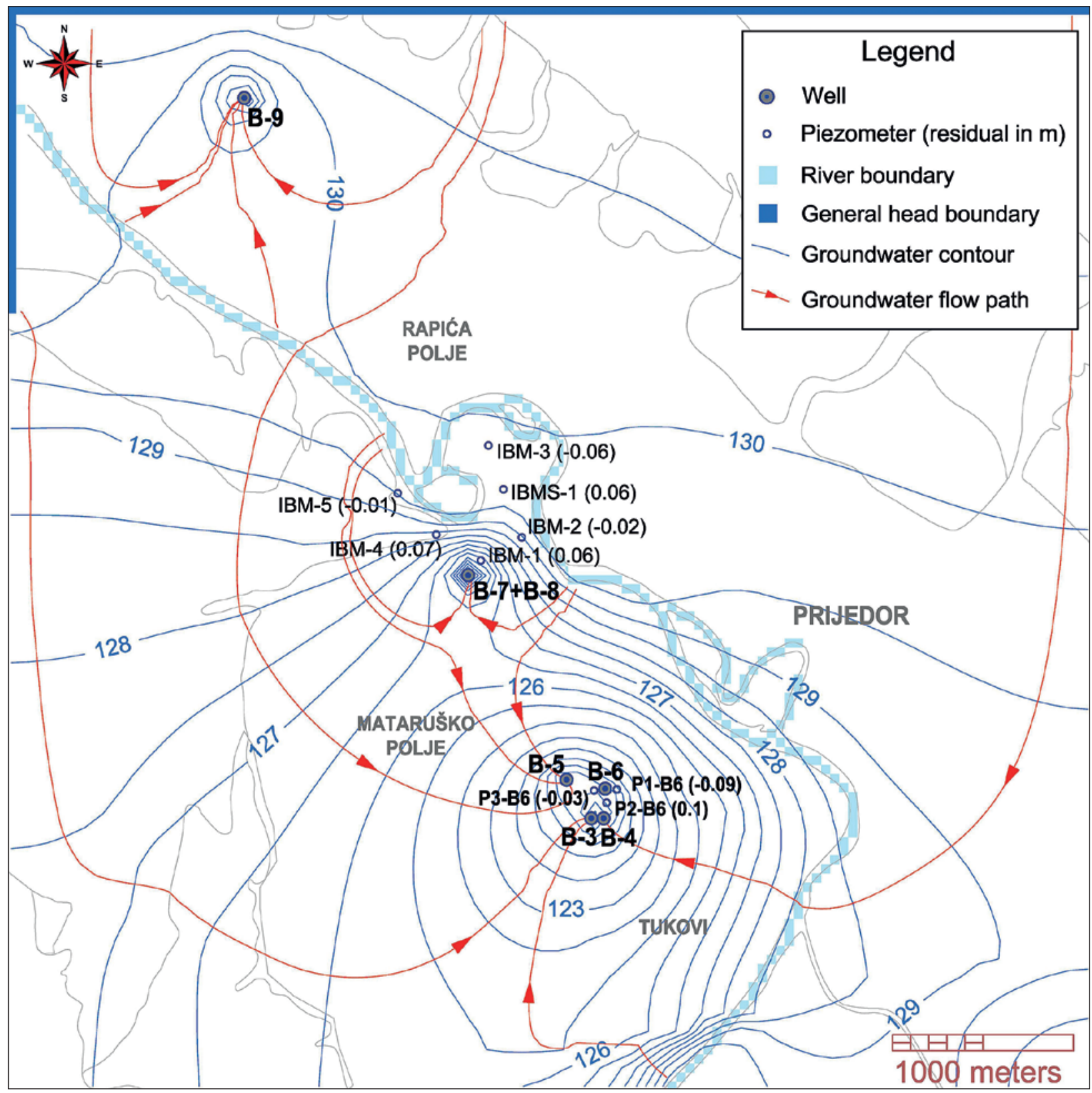

Fig. 9: Boundary conditions, groundwater contours and flow paths of the karst aquifer, and residuals at piezometers (17 June 2003).

According to prior hydrogeological research in this area (Josipović 1971, Polomčić et al. 2005a), it was obvious that the faults are preferential pathways of karst groundwater flow. The regional fault zone with a northwest-southeast orientation, which generally coincides with the recent riverbed of the Sana, is the main water circulation zone in the karst aquifer. The faults in this zone, along with the faults of a southwest to northeast trend, are the preferential pathways. The results of the test of the group of wells (B-7 and B-8, June 2003), $350 \mathrm{~m}$ from the Sana River, provided corroborative evi- dence. The total pumping test capacity of the two wells was $152 \mathrm{l} / \mathrm{s}$, with a drawdown of only $1.51 \mathrm{~m}$, a hydraulic transmissivity of $8.55 \cdot 10^{-2} \mathrm{~m}^{2} / \mathrm{s}$ and a storage coefficient of $2.67 \cdot 10^{-2}$ (Polomčić et al. 2005).

The influence of the fault zones and the spatial anisotropy of the karst aquifer were simulated on the hydrodynamic model by different conductivity values on the $\mathrm{x}$ and $\mathrm{y}$ axes of the Cartesian coordinate system (Fig. 10). The values of hydraulic conductivity for the faults of southwest to northeast direction, derived from model calibration, were $\mathrm{K}_{\mathrm{x}}=2.5 \cdot 10^{-3} \mathrm{~m} / \mathrm{s}$ and $\mathrm{K}_{\mathrm{y}} 1 \cdot 2 \cdot 10^{-3} \mathrm{~m} / \mathrm{s}$. At 


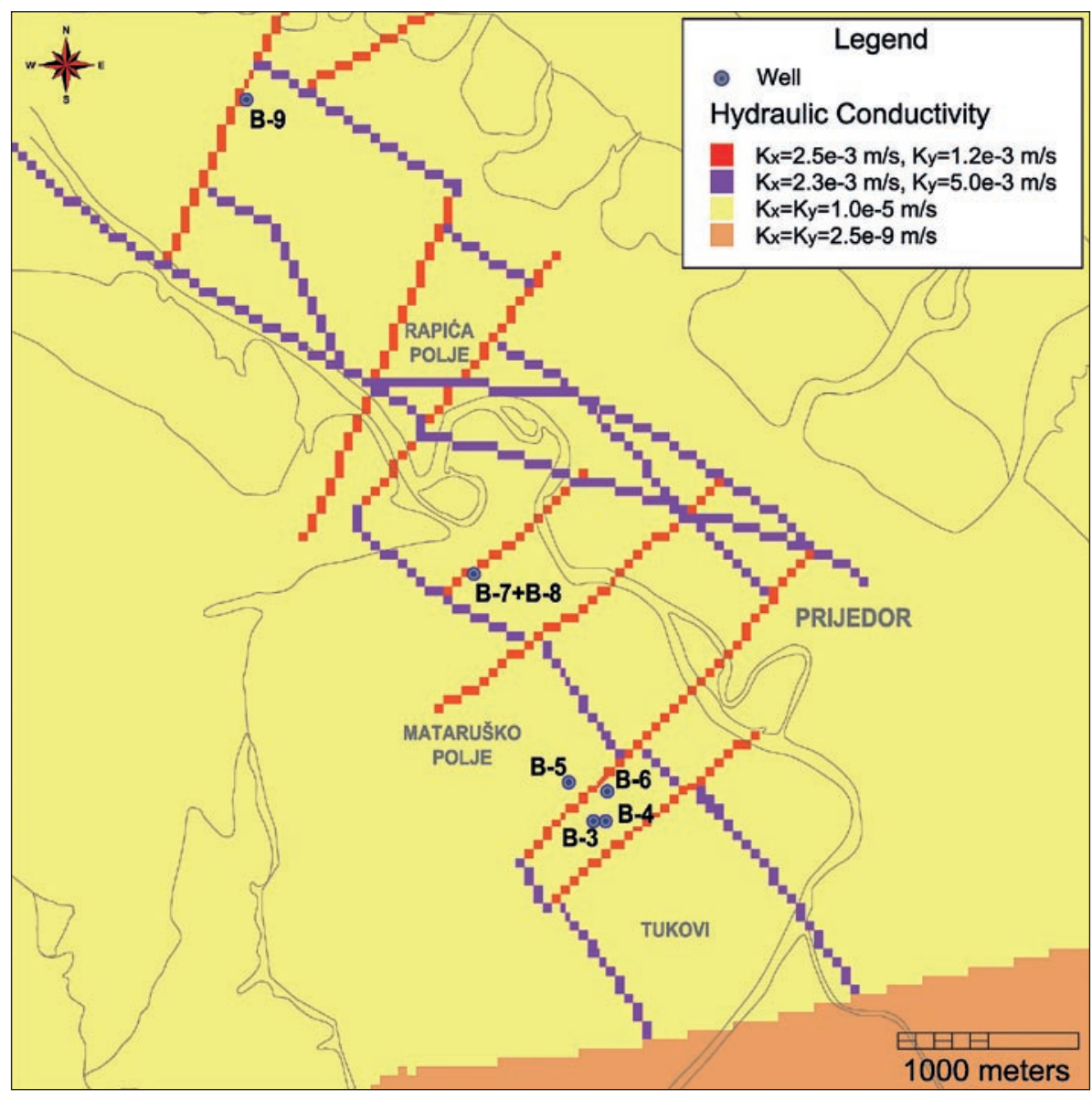

Fig. 10: Fault zones of influence on groundwater flow simulated by different hydraulic conductivities on $x$ and $y$ axes of the coordinate system.

the same time, the hydraulic conductivity obtained from pumping test analysis of wells B-7 and B-8, which are located in the fault zone, was $2.13 \cdot 10^{-3} \mathrm{~m} / \mathrm{s}$. This indicated a relatively good match of the pumping test data with representative values of hydraulic conductivity derived from manual and PEST model calibration. For the faults of northwest to southeast direction, the values of hydraulic conductivity of $\mathrm{K}_{\mathrm{x}}=2.3 \cdot 10^{-3} \mathrm{~m} / \mathrm{s}$ and $\mathrm{K}_{\mathrm{y}}=5.0 \cdot 10^{-3} \mathrm{~m} / \mathrm{s}$ were used.

\section{RESULTS AND DISCUSSION}

The water budget of the karst aquifer was assessed at two points in time: minimum (10 Sep. 2003) and maximum (5 Feb. 2003) water levels of the Sana, separately for withdrawal from the source areas only $(\Sigma Q=280.60 \mathrm{l} / \mathrm{s})$ and including the additional capacity of wells B-7 and B- 8 of 152 1/s (Tab. 4).

Changes in the contributions of the Sana River surface water, groundwater in the karst aquifer and underground recharge $(\mathrm{GHB})$ are apparent for model inflow rates in different model variants.

During periods of minimal river stages, for the case where only the active groundwater sources are in service, the flow to the area of the model consists of in- filtration from the Sana River $(86.6 \%, 161.05 \mathrm{l} / \mathrm{s})$, underground recharge from the surrounding karst aquifer $(12.13 \%)$, and infiltration of precipitation (1.85\%). For the same period, when wells B-7 and B- 8 are operating at a total discharge rate of $432.60 \mathrm{l} / \mathrm{s}$, a reduction in underground outflow and also an increase in underground recharge were noted. In that case, an increase in infiltration from the Sana River and a significant contribution of the karst aquifer groundwater storage (up to $97 \%$ ) were evident. Under these conditions, the total inflow (and outflow) was increased by $43.8 \%$, while during high stages of the Sana River the water budget increased by $38.5 \%$. 
Tab. 4: Groundwater budget of the karst aquifer in the Sana Valley.

\begin{tabular}{|l|c|c|c|c|c|c|c|c|}
\hline \multirow{2}{*}{$\begin{array}{l}\text { Sana water } \\
\text { level }\end{array}$} & \multicolumn{4}{|c|}{ Minimum } & \multicolumn{4}{c|}{$\begin{array}{c}\text { Maximum } \\
121.93 \mathrm{~m} \text { (5 Feb. 2003) }\end{array}$} \\
\hline $\begin{array}{l}\text { Operating } \\
\text { wells }\end{array}$ & \multicolumn{2}{|c|}{ Standard operation } & \multicolumn{2}{|c|}{$\begin{array}{c}\text { Including } \\
\text { B-7 and B-8 }\end{array}$} & \multicolumn{2}{|c|}{ Standard operation } & \multicolumn{2}{c|}{$\begin{array}{c}\text { Including } \\
\text { B-7 and B-8 }\end{array}$} \\
\hline $\begin{array}{l}\text { Boundary } \\
\text { conditions }\end{array}$ & $\begin{array}{c}\text { Model } \\
\text { inflow } \\
(1 / \mathrm{s})\end{array}$ & $\begin{array}{c}\text { Model } \\
\text { outflow } \\
(1 / \mathrm{s})\end{array}$ & $\begin{array}{c}\text { Model } \\
\text { inflow } \\
(1 / \mathrm{s})\end{array}$ & $\begin{array}{c}\text { Model } \\
\text { outflow } \\
(1 / \mathrm{s})\end{array}$ & $\begin{array}{c}\text { Model } \\
\text { inflow } \\
(1 / \mathrm{s})\end{array}$ & $\begin{array}{c}\text { Model } \\
\text { outflow } \\
(1 / \mathrm{s})\end{array}$ & $\begin{array}{c}\text { Model } \\
\text { inflow } \\
(1 / \mathrm{s})\end{array}$ & $\begin{array}{c}\text { Model } \\
\text { outflow } \\
(1 / \mathrm{s})\end{array}$ \\
\hline Sana River & 161.05 & 16.54 & 181.16 & 7.41 & 197.14 & 34.77 & 297.31 & 19.17 \\
\hline Wells & & 280.60 & & 432.60 & & 280.60 & & 432.60 \\
\hline $\begin{array}{l}\text { General head } \\
\text { boundary }\end{array}$ & 22.71 & 6.28 & 19.64 & 2.11 & 31.58 & 7.12 & 52.29 & 3.81 \\
\hline Recharge & 3.47 & $\mathbf{6}$ & 3.47 & & 51.38 & & 51.38 & \\
\hline Storage & 122.14 & 6.57 & 241.46 & 3.72 & 54.25 & 11.62 & 62.13 & 7.74 \\
\hline Total & $\mathbf{3 0 9 . 3 7}$ & $\mathbf{3 0 9 . 9 9}$ & $\mathbf{4 4 5 . 7 3}$ & $\mathbf{4 4 5 . 8 4}$ & $\mathbf{3 3 4 . 3 5}$ & $\mathbf{3 3 4 . 1 1}$ & $\mathbf{4 6 3 . 1 1}$ & $\mathbf{4 6 3 . 3 2}$ \\
\hline
\end{tabular}

In periods of high river stages, in the case of additional karst groundwater extraction (wells B7 and B-8), the most intense budget changes were attributed to surface water infiltration (increased contribution by $53.9 \%$ ). Karst aquifer groundwater storage abstraction was increased by only $14.53 \%$, which is $179.331 /$ s less compared to the amount in periods of minimal river stages. During wet periods, infiltration of rainfall is more significant for the total budget (11.09\%), which was found to be approximately the same as the inflow from the surrounding karst aquifer (11.29\%).

The participation of the alluvial aquifer in the groundwater budget is not significant. This is a result of the small thickness of the sediments and the transport function between the Sana River and the karst aquifer, in areas where the Sana riverbed is not in direct contact with the karst rocks. During dry periods, when only the active groundwater sources are in service, the alluvial aquifer is drained into the Sana River at a rate of $6.81 \mathrm{l} / \mathrm{s}$, which is $41.17 \%$ of the total discharge into the river. When the two new wells (B-7 and B-8) are operating, the drainage of the alluvial aquifer into the Sana River is considerably reduced $(2.13 \mathrm{l} / \mathrm{s})$.

\section{CONCLUSION}

This study showed that hydrodynamic modeling can be very useful for simulating recharge and discharge conditions of different types of aquifers, including those featuring karst porosity. The hydrodynamic regional model of the Prijedor groundwater source has successfully described the relationships of the alluvial, Pliocene and karst aquifers and the Sana River, which was one of the main tasks of the research reported in this paper.

The main source of groundwater recharge is infiltration from the Sana River through alluvial deposits that overlie karstified rocks extensively in the study area. During dry periods, the contribution of river infiltration to the groundwater budget declines and, as a result, the extraction of the karst aquifer storage reserves increases. The model showed that even in these periods, ground- water exploitation from the karst aquifer is efficient and sustainable.

The biggest challenge in the development of the hydrodynamic model was to represent groundwater flow through the karst aquifer adequately. Numerous karst groundwater models have been developed in an attempt to simulate groundwater movement through karst tertiary (conduit) porosity, which requires very detailed hydrogeological exploration. Keeping in mind that faults are the preferential directions of groundwater flow in the study area, the karst aquifer with its spatial anisotropy was simulated by assigning different hydraulic conductivities on the $\mathrm{x}$ - and $\mathrm{y}$-axes $\left(\mathrm{K}_{\mathrm{x}}, \mathrm{K}_{\mathrm{y}}\right)$ for two systems of faults. The results of calibration and minimal differences between measured and simulated 
groundwater levels corroborated that a proper methodology was applied.

The model was used not only to define the rechargedischarge conditions, but also to simulate the direction and rate of the groundwater flow in the aquifer and to assess the groundwater budget, which is essential for long term protection and sustainable use of the groundwater sources.
Further work related to this regional aquifer should focus on a more detailed monitoring program, which would include hydrological surveys of the Sana River flow at different sections in the model area, in order to better understand the infiltration patterns during different periods of the year.

\section{ACKNOWLEDGEMENTS}

Our thanks are due to Igor Jemcov, assistant professor at the Belgrade University, Faculty of Mining and Geology, Department of Hydrogeology, for his generous assistance and advice that undoubtedly helped to improve the presented research results. We wish to acknowledge our indebtedness to JP Vodovod Prijedor (Prijedor water supply utility) who made possible the detailed research and groundwater observation from 2002 to 2004 .

\section{REFERENCES}

Bajić, D. \& D. Polomčić, 2008: 3D Hydrogeological Model of the Buvac Limonite Ore Body, Republic Srpska, Bosnia and Herzegovina.- In Pavlović, V. (ed.). Proceedings of $4^{\text {th }}$ International Conference 'Coal 2008', 15 $5^{\text {th }}-18^{\text {th }}$ October 2008, Belgrade. Yugoslav Opencast Mining Committees, $1-9$, Belgrade.

Cheng, J.M. \& C.X. Chen, 2004: An integrated linear/non-linear flow model for the conduit-fissure-pore media in the karst triple void aquifer system.- Environmental Geology 47, 2, 163-174

Cornaton, F. \& P. Perrochet, 2002: Analytical 1D dual porosity equivalent solution to $3 \mathrm{D}$ discrete single continuum models: application to karstic spring hydrograph modelling.- Journal of Hydrology 262, 1-4, 165-176

Cvijić, R., 2004: Geomanagement Related to Utilization and Development of Ljubija Metallogenic Province Mineral Resources (in Serbian).- RŽR 'Ljubija" Prijedor, Mining institute Prijedor, pp. 350, Prijedor.

Field, M.S., 1997: Risk assessment methodology for karst aquifers: (2) Solute-transport modeling.- Environmental Monitoring and Assessment, 47, 1, 23-37.

Grubić, A., Protić, Lj., Filipović, I. \& D. Jovanović, 2000: Correlation of Carboniferous, Permian and Triassic Sequences of the Jadar Block and the Sana-Una terrains (in Serbian).- In: Karamata, S. \& S. Janković (eds.) Proceedings of the International Symposium "Geology and Metallogeny of the Dinarides and the Vardar Zone", Banja Luka, Academy of Sciences and Arts of the Republic of Srpska, 72-78, Banja Luka
Ford D. \& P. Williams, 2007: Karst hydrogeology and geomorphology.- John Wiley and Sons Ltd, pp. 576, West Sussex, England.

Harbaugh, A.W., Banta, E.R., Hill, M.C. \& M.G. McDonald, 2000: MODFLOW-2000: The U.S. Geological Survey Modular Ground-Water Model. User Guide to Modularization Concepts and the Ground-Water Flow Process. U.S. Geological Survey, Report number: 00-92

Josipović, J., 1971: Hydrogeological Solutions to the Prijedor and Brčko Water Supply (in Serbian).- In: Proceedings of the $1^{\text {st }}$ Symposium on Hydrogeology and Engineering Geology of Yugoslavia, Herceg Novi, Jugoslovenski komitet za hidrogeologiju, inženjersku geologiju i geofiziku, 85-94, Belgrade

Jovanović, L., Đurić, N. \& S. Glavaš, 1998: Contribution to the Study of Groundwater Budget in the Republic Srpska (in Serbian).- In: Proceedings of the Conference "Two millennia of mining in Srebrenica", Srebrenica, 129-135, Srebrenica

Jurić, M. 1970: Geology of the Sana Palaeozoic in NW Bosnia (in Serbian). Geološki glasnik, Bulletin Géologique, 14. 28-36, Prijedor

Jurić, M., 1977: Textual Explanation of the Base Geological Map at Scale 1:100,000, Sheet Prijedor (in Serbian). Savezni geološki zavod, pp. 55., Belgrade.

Király L., 2003: Karstification and groundwater flow.- Speleogenesis and Evolution of Karst Aquifers 1,3, 1-26 
Kovacs A. \& M. Sauter, 2007: Modeling karst hydrodynamics.In: Goldscheider N., Drew D. (eds) Methods in Karst Hydrogeology. IAH: International Contribution to Hydrogeology, vol 26, Taylor and Francis, pp 201-222, London

Mohrlok U., Kienle J. \& G. Teutsch, 1997: Parameter identification in double-continuum models applied in karst aquifers.- Proceedings of the 12th International Congress of Speleology, Vol 2. La, 163-166, Chaux-de-Fonds, Switzerland

Ostojić, Đ., 1974: Omarsko Polje Groundwater Budget (in Serbian). Proceedings of the $3^{\text {rd }}$ Yugoslavian Symposium on Hydrogeology and Engineering Geology, 22 ${ }^{\text {th }}-26^{\text {th }}$ April 1974, Opatija, Jugoslovenski komitet za hidrogeologiju, inženjersku geologiju i geofiziku, 213-223, Belgrade.

Polomčić, D., 2002: Hydrogeological System Schematization Types for Hydrodynamic Modeling (in Serbian).- In: Radenković Ž. (ed.). Proceedings of $13^{\text {th }}$ Yugoslavian Symposium on Hydrogeology and Engineering Geology, 30 ${ }^{\text {th }}$ May $-2^{\text {nd }}$ June 2002, Herceg Novi. Faculty of Civil Engineering Montenegro and Geozavod Beograd, 389-396, Belgrade.

Polomčić, D., 2004: The Influence of the Space and Time Discretizaton on the Correctness of the Hydrodynamic Model Results (in Serbian).- Bulletin of Geoinstitute, 39, 197-209, Belgrade.

Polomčić, D., Dragišić, V. \& V. Živanović, 2005a: Hydrogeological Model of the Mataruško Polje-Tukovi Groundwater Resource (in Serbian).-In: Rundić, Lj. (ed.) Proceedings of $14^{\text {th }}$ Congress of Serbian and Montenegrin Geologists, $18^{\text {th }}$ $20^{\text {th }}$ October 2005, Novi Sad. Serbian Geological Society, 505-509, Belgrade.

Polomčić, D., Dragišić, V. \& V. Živanović, 2005b: Hydrodynamic Model of the Groundwater Source for Water Supply of Prijedor Town, Republic of Srpska.- In: Stevanović, Z. \& P. Milanović (eds.) Water resources and environmental problems in karst, Proceedings of the international conference and field seminars, $13^{\text {th }}-19^{\text {th }}$ September 2005, Belgrade, Kotor. ZUHRA, 365-370, Belgrade.
Polomčić, D., 2009: Hydrodynamical Model of Groundwater Regime in the Buvac Limonite Ore Body, Republic of Srpska, Bosnia and Herzegovina.- In Pavlović V. (ed.). Proceedings of $4^{\text {th }}$ International Conference 'Coal 2008', $15^{\text {th }}-18^{\text {th }}$ October 2008, Belgrade. Yugoslav Opencast Mining Committees, 392-406, Belgrade.

Polomčić, D., 2012: Hydrodynamic model of Pirot basin and karst massif of Stara planina mt.- In Stevanović Z., Ristić Vakanjac V. \& S. Milanović (eds.) Climate Change and Impacts on Water Supply. University of Belgrade, pp. 391416, Belgrade

Scanlon, B.R., Mace, R.E., Barret, M.E. \& B. Smith, 2003: Can we simulate regional groundwater flow in a karst system using equivalent porous media models?: Case study, Barton springs Edwards aquifer, USA.- Journal of Hydrology $276,1-4,137-158$

Stevanović, Z. \& V. Dragišić, 1997: An example of regulation of karst aquifer.- In: Gunay, G. and I. Johnson (eds.) Karst waters and environmental impacts. Balkema, pp 19-26, Rotterdam,

Teutsch G., 1993: An extended double-porosity concept as a practical modeling approach for a karstified terrain.- In: Günay G., Johnson A.I. \& W. Back (eds.) Hydrogeological processes in Karst Terranes. Proceedings of the Antalya symposium and field seminar, Antalya, Turkey, October 1990: International Association of Hydrological Sciences, Publication No. 207, pp 281-292, Wallingford. 